\title{
Clinical and biochemical assessment of a modified evaporated milk for infant feeding
}

\author{
N. R. BELTON, F. COCKBURN, J. O. FORFAR, M. M. GILES, J. KIRKWOOD, J. SMITH, \\ D. THISTLETHWAITE, T. L. TURNER, AND E. M. WILKINSON
}

From the Department of Child Life and Health, University of Edinburgh, and Simpson Memorial Maternity Pavilion, Royal Infirmary, Edinburgh

SUMmARY A clinical and biochemical evaluation has been made of a new milk formula, Modified Carnation milk (MCM), based on cows' milk but with the mineral content and concentration of caloric nutrients altered to make it correspond more closely to human milk. MCM produced higher plasma calcium and magnesium concentrations in 6-day-old infants than those produced by unmodified evaporated and dried milks, achieving concentrations closer to those of breast milk. Plasma free amino acid concentrations in MCM-fed infants are nearer breast-fed values than those in unmodified milk-fed infants where higher individual plasma amino acid concentrations persist during the first 3 months. MCM-fed infants had low plasma urea concentrations and lower urine osmolalities at 6 days, 3 weeks, 6 weeks, 3 months, and 6 months than infants fed on the evaporated and dried milks, and similar plasma urea and urine osmolalities to those of breast-fed infants.

MCM is likely to be superior to unmodified evaporated and dried milks in preventing convulsions of the hypocalcaemic/hypomagnesaemic/hyperphosphataemic type, and seems less likely to cause hypertonic dehydration. MCM is easily prepared, readily accepted by babies, and appears to be nutritionally adequate for the feeding of term infants.

A recent report recommends that mothers should breast feed their babies for a minimum of 2 weeks and preferably for the first 4 to 6 months of life (Department of Health and Social Security, 1974). Cows' milk, usually modified (Gerstenberger and Ruth, 1919), has long been used as a substitute for breast milk but recently there has been a tendency to make milk-based formulae resemble human milk more closely in terms of nutritional composition in the belief that this is better for the growing infant. Because of considerable evidence that existing infant formulae based on cows' milk provoke neonatal tetany, with hypocalcaemia, hyperphosphataemia, and hypomagnesaemia (Bakwin, 1937; Gittleman and Pincus, 1951; Oppé and Redstone, 1968; Cockburn et al., 1973) and/or hypernatraemic dehydration (Taitz and Byers, 1972; Oates, 1973; Davies, 1973; Shaw et al., 1973) the main modifications in manufacture have been to reduce the total solute load of the formula, usually by reducing the protein and mineral contents.

In this study, comparison has been made between groups of newborn infants fed:

(i) breast milk (BM), (ii) modified evaporated Received 20 May 1976 milk 'Carnation', a new milk-based infant formula (MCM), (iii) standard evaporated milk 'Carnation' (SCM), and (iv) full-cream dried milk, 'Ostermilk No. 2' (OM2). The new modified Carnation milk differs from the other formulae in that the mineral content and concentration of calorific nutrients in fresh cows' milk have been altered to conform more closely to values found in human milk by the addition of a vegetable oil mixture (corn oil and coconut oil) and a carbohydrate solution containing glucose solids. The compositions of the three artificial milk formulae and breast milk are compared in Table 1.

\section{Patients and methods}

Infants from three wards in the Maternity Hospital were fed from birth on MCM, SCM, and OM2 respectively, one type of feed only being used on each ward. Mothers wishing to breast feed were encouraged to do so. During the first few days after the birth of their baby, mothers were informed about the study and those who consented to take part were thus already in one of the four groups. 101 patients, all Caucasian, effectively participated.

A heel-prick blood sample was taken at the same 
Table 1 Composition of infant formulae (per $100 \mathrm{ml}$ )

\begin{tabular}{|c|c|c|c|c|}
\hline & Breast milk & Ostermilk No. 2 & Modified Carnation & Standard Carnation \\
\hline Calories, kcal (kJ) & $67(280)$ & $69 *(288)$ & $68(284)$ & $67 *(280)$ \\
\hline Protein (g) & $1 \cdot 3$ & $3 \cdot 3$ & $1 \cdot 9$ & $2 \cdot 7$ \\
\hline Fat $(\mathrm{g})$ & $3 \cdot 7$ & $3 \cdot 3$ & $3 \cdot 7$ & $2 \cdot 9$ \\
\hline Carbohydrate (g) & $7 \cdot 3$ & $6 \cdot 7^{*}$ & $7 \cdot 0 \dagger$ & $7 \cdot 6^{*}$ \\
\hline \multicolumn{5}{|l|}{ Minerals } \\
\hline Calcium (mg) & 35 & 114 & 64 & 95 \\
\hline Phosphorus (mg) & 14 & 91 & 52 & 83 \\
\hline Magnesium (mg) & $3 \cdot 0$ & $12 \cdot 3$ & $8 \cdot 8$ & $11 \cdot 6$ \\
\hline Sodium $(\mathrm{mg})$ & 20 & 56 & 32 & 50 \\
\hline Potassium (mg) & 62 & 138 & 73 & 133 \\
\hline \multicolumn{5}{|c|}{ Fatty acids (as a $\%$ of total) } \\
\hline Saturated & 53 & 64 & 52 & 65 \\
\hline C10.0 (capric) & $1 \cdot 3$ & $2 \cdot 5$ & $2 \cdot 5$ & $2 \cdot 7$ \\
\hline C12.0 (lauric) & $5 \cdot 6$ & $2 \cdot 7$ & $8 \cdot 4$ & $2 \cdot 6$ \\
\hline C14.0 (myristic) & $7 \cdot 6$ & $11 \cdot 0$ & $8 \cdot 1$ & $9 \cdot 6$ \\
\hline C16.0 (palmitic) & $27 \cdot 1$ & $28 \cdot 2$ & $19 \cdot 0$ & $23 \cdot 4$ \\
\hline C18.0 (stearic) & $9 \cdot 3$ & $13 \cdot 8$ & $6 \cdot 9$ & $9 \cdot 7$ \\
\hline Unsaturated & 47 & 36 & 48 & 35 \\
\hline Monounsaturated & 39 & 34 & 28 & 33 \\
\hline C16.1 palmitoleic & $4 \cdot 2$ & $2 \cdot 6$ & $1 \cdot 1$ & $2 \cdot 2$ \\
\hline C18.1 oleic & $34 \cdot 3$ & $31 \cdot 7$ & $26 \cdot 1$ & $28 \cdot 6$ \\
\hline Polyunsaturated & 8 & 2 & 20 & 2 \\
\hline C18.2 linoleic & $7 \cdot 2$ & $1 \cdot 8$ & $19 \cdot 8$ & $1 \cdot 8$ \\
\hline C18.3 linolenic & $0 \cdot 7$ & Trace & Trace & - \\
\hline
\end{tabular}

*Includes sucrose added in preparation when the milk is made up according to manufacturer's instructions. †Lactose $2 \cdot 7 \mathrm{~g}$, glucose solids $4 \cdot 3 \mathrm{~g}$ (principally disaccharides and higher saccharides).

time as the Guthrie test sample on the sixth day of life and a urine sample was collected on the sixth day. Crown-rump length, occipitofrontal head circumference, and skinfold thickness in the triceps, subscapular and suprailiac regions were measured on the first and sixth days of life. Skinfold thickness was measured by the method of Tanner (1973) using Holtain skinfold calipers. Mothers and their infants were seen again at 3 weeks, 6 weeks, 3 months, and 6 months of age. Blood (heel prick) and urine samples were collected at each of these times and the anthropometric measurements repeated. On all blood samples total protein, sodium, potassium, calcium, magnesium, phosphorus, haemoglobin, and haematocrit were estimated but because of the small amounts of blood available plasma urea was estimated only on 6-day and 3month samples, plasma glucose on 6-day samples, total plasma lipids on 6-week and 6-month samples, and both plasma cholesterol and nonesterified fatty acids on 6-day, 6-week, and 6-month samples. Concentrations of plasma-free amino acids and urea were measured in pooled specimens from all blood samples in each of the four groups $(20 \mu \mathrm{l}$ plasma from 10 infants; and stored at $-70^{\circ} \mathrm{C}$ until analysed). Plasma osmolality was measured on some 6-day samples, and urine osmolality on all the urine samples.
$\mathrm{Ca}, \mathrm{Mg}, \mathrm{Na}$, and $\mathrm{K}$ were estimated by atomic absorption spectrophotometry using a Unicam SP 90 spectrophotometer (Unicam instruction sheets $\mathrm{Ca} 1, \mathrm{Mg} 1, \mathrm{Na} 1, \mathrm{~K} 2)$; total protein by an ultramicro adaptation of the methods of Kingsley (1939) and Gornall et al. (1949) using a modified biuret reagent; phosphorus by a micromethod based on the method of Fiske and Subbarow (1925); urea by a urease catalysis and phenol/hypochlorite reaction method based on that of Fawcett and Scott (1960). Total plasma lipids were estimated using a Boehringer method based on the procedure of Zöllner and Kirsch (1962); cholesterol by the method of Jamieson (1964) and nonesterified fatty acids by the method of Novak (1965); plasma glucose by the glucose oxidase technique (Raabo and Terkildsen, 1960); and microhaematocrit and haemoglobin in the standard way. Osmolality was measured with the Advanced Instruments Osmometer, type 3LAS or $3 \mathrm{~W}$, and plasma amino acids by column chromatography (Cockburn et al., 1971).

\section{Results}

\section{Biochemical aspects.}

Plasma calcium (Table 2). BM-fed infants had a higher mean plasma $\mathrm{Ca}$ at 6 days $(2 \cdot 55 \mathrm{mmol} / \mathrm{l}$; 
Table 2 Plasma and urine biochemical values for infants fed four different milks: breast milk (BM), Ostermilk 2 (OM2), modified Carnation (MCM), and Carnation (SCM)

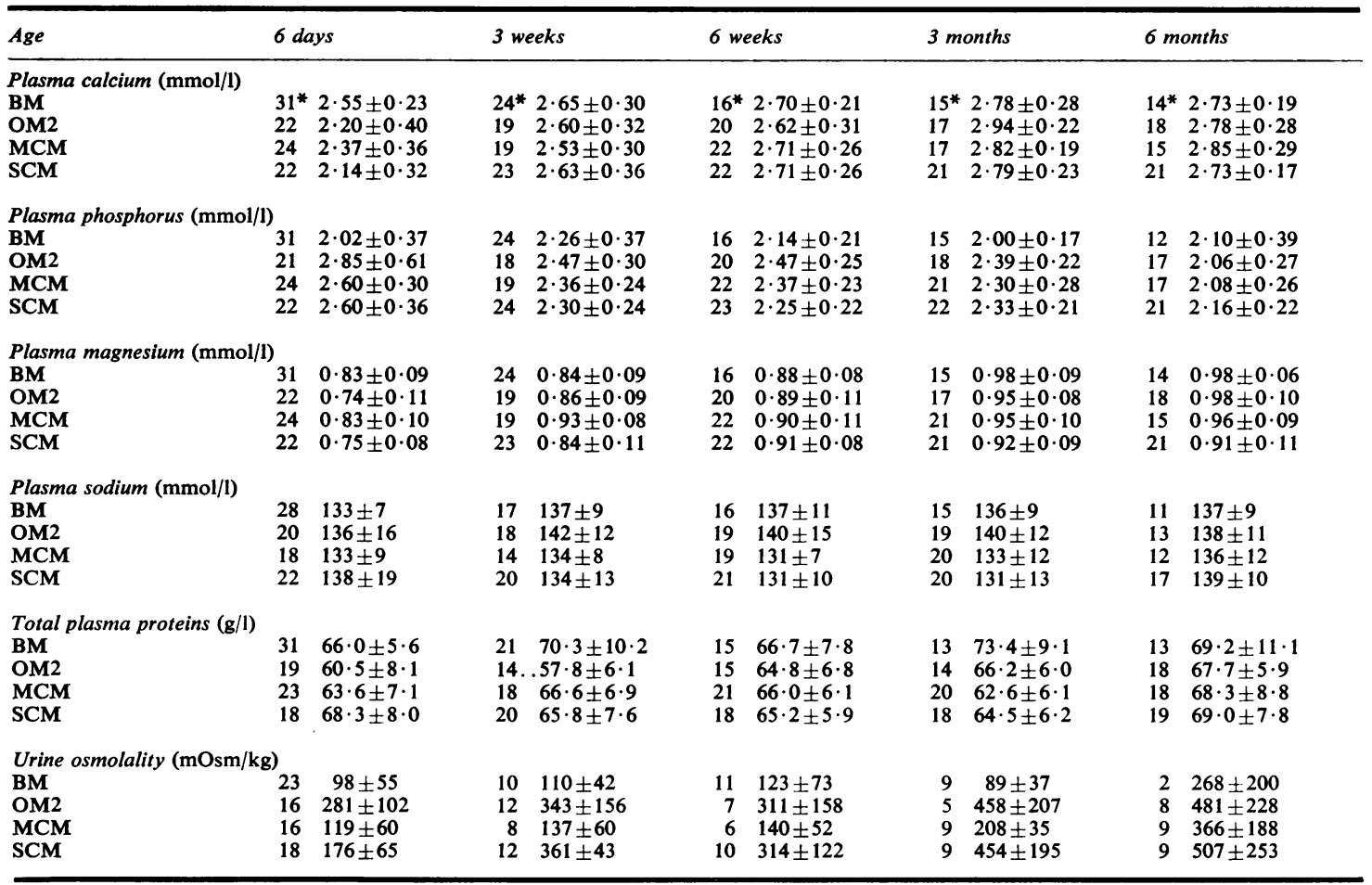

* The number of samples is given, followed by the mean $\pm S D$.

Conversion: SI to traditional units-Calcium: $1 \mathrm{mmol} / 1 \approx 4 \mathrm{mg} / 100 \mathrm{ml}$. Phosphorus: $1 \mathrm{mmol} / 1 \approx 3 \cdot 1 \mathrm{mg} / 100 \mathrm{ml} . \mathrm{Magnesium}: 1 \mathrm{mmol} / 1 \approx 2 \cdot 4$ $\mathrm{mg} / 100 \mathrm{ml}$. Sodium: $1 \mathrm{mmol} / \mathrm{l} \approx 1 \mathrm{mEq} / 1$.

$10 \cdot 2 \mathrm{mg} / 100 \mathrm{ml})$ than infants on any of the other three milks $(P<0 \cdot 01)$. However at 6 days $\mathrm{Ca}$ in infants fed with MCM $(2 \cdot 37 \mathrm{mmol} / 1 ; 9 \cdot 5 \mathrm{mg} / 100$ $\mathrm{ml})$ was higher $(\mathrm{P}<0.05)$ than with $\mathrm{SCM}(2 \cdot 14$ $\mathrm{mmol} / 1 ; 8 \cdot 6 \mathrm{mg} / 100 \mathrm{ml})$, and higher, but not significantly so, than with $\mathrm{OM} 2(2 \cdot 20 \mathrm{mmol} / 1 ; 8 \cdot 8 \mathrm{mg} /$ $100 \mathrm{ml})$. From 3 weeks onwards there was very little difference between any of the milks.

Plasma phosphorus (Table 2). Mean plasma $\mathrm{P}$ with BM $(2.02 \mathrm{mmol} / 1 ; 6.3 \mathrm{mg} / 100 \mathrm{ml})$ was lower $(\mathrm{P}<0.01)$ at 6 days than with all other milks (SCM $2 \cdot 60 \mathrm{mmol} / 1,8 \cdot 1 \mathrm{mg} / 100 \mathrm{ml}$; MCM $2 \cdot 60$ $\mathrm{mmol} / \mathrm{l}, \quad 8 \cdot 1 \mathrm{mg} / 100 \mathrm{ml}$; OM2 $2 \cdot 85 \mathrm{mmol} / 1$, $8.9 \mathrm{mg} / 100 \mathrm{ml}$ ). It was also significantly lower than with MCM at 6 weeks $(2 \cdot 14 / 2 \cdot 37 \mathrm{mmol} / 1 ; 6 \cdot 7 / 7 \cdot 4$ $\mathrm{mg} / 100 \mathrm{ml})$ and 3 months $(2 \cdot 00 / 2 \cdot 30 \mathrm{mmol} / 1$; $6 \cdot 3 / 7 \cdot 2 \mathrm{mg} / 100 \mathrm{ml}) ; \mathrm{SCM}$ at 3 months $(2 \cdot 00 / 2 \cdot 33$ $\mathrm{mmol} / 1 ; 6 \cdot 3 / 7 \cdot 3 \mathrm{mg} / 100 \mathrm{ml})$; and OM2 at 3 weeks $(2 \cdot 26 / 2 \cdot 47 \mathrm{mmol} / 1 ; 7 \cdot 1 / 7 \cdot 7 \mathrm{mg} / 100 \mathrm{ml}), 6$ weeks $(2 \cdot 14 / 2 \cdot 47 \mathrm{mmol} / 1 ; 6 \cdot 7 / 7 \cdot 7 \mathrm{mg} / 100 \mathrm{ml})$, and 3 months $(2 \cdot 00 / 2 \cdot 39 \mathrm{mmol} / 1 ; 6 \cdot 3 / 7 \cdot 4 \mathrm{mg} / 100 \mathrm{ml})$.
Plasma magnesium (Table 2). BM-fed infants $(0.83 \mathrm{mmol} / 1 ; 2.02 \mathrm{mg} / 100 \mathrm{ml})$ and infants fed on MCM $(0.83 \mathrm{mmol} / 1 ; 2 \mathrm{mg} / 100 \mathrm{ml})$ had higher mean plasma $\mathrm{Mg}$ values at 6 days than infants fed on SCM $(0.75 \mathrm{mmol} / \mathrm{l} ; 1.83 \mathrm{mg} / 100 \mathrm{ml})$ and OM2 $(0.74 \mathrm{mmol} / \mathrm{l} ; 1.81 \mathrm{mg} / 100 \mathrm{ml})(P<0.02$ in all cases). At 3 weeks $\mathrm{Mg}$ was still higher with $\mathrm{MCM}$ $(0.93 \mathrm{mmol} / \mathrm{l} ; 2.26 \mathrm{mg} / 100 \mathrm{ml})$ than with $\mathrm{SCM}$ $(0.84 \mathrm{mmol} / \mathrm{l} ; 2.04 \mathrm{mg} / 100 \mathrm{ml} ; \mathrm{P}<0.05)$ and OM2 (0.86 mmol/1, $2 \cdot 10 \mathrm{mg} / 100 \mathrm{ml} ; \mathrm{P}<0 \cdot 01)$.

Plasma sodium (Table 2). MCM produced mean $\mathrm{Na}$ concentrations similar to those in BM-fed infants. The mean $( \pm \mathrm{SD})$ with $\mathrm{OM} 2(142 \pm 12 \mathrm{mmol} / \mathrm{l}$; $142 \pm 12 \mathrm{mEq} / \mathrm{l})$ was higher than with $\mathrm{MCM}(134 \pm 8$, $P<0.05)$ at 3 weeks, and higher than with SCM at 3 weeks $(P<0.01), 6$ weeks $(P<0.01)$, and 3 months $(P<0.05)$. Hypernatraemia was seen in all groups; 4 out of $87(5 \%)$ plasma sodiums in the BM, 6 out of $89(7 \%)$ in the OM2, 4 out of $83(5 \%)$ in the MCM, and 5 out of $100(5 \%)$ in the SCM groups were $155 \mathrm{mmol} / \mathrm{l}$ or greater. 
Plasma potassium. Mean plasma potassium concentrations with OM2 tended to be higher than with the other three milks, though no significant differences were present at 6 days of age. Values with $\operatorname{BM}(5 \cdot 2 \pm 0 \cdot 4 \mathrm{mmol} / 1 ; 5 \cdot 2 \pm 0 \cdot 4 \mathrm{mEq} / \mathrm{l})$ were lower than with OM2 $(5 \cdot 9 \pm 0 \cdot 2)$ at 6 weeks and 3 months $(5 \cdot 1 \pm 0 \cdot 5 / 5 \cdot 6 \pm 0 \cdot 6)(P<0.01$ in both instances), and lower than with $\operatorname{MCM}(5 \cdot 6 \pm 0 \cdot 7)$ at 6 weeks $(P<0.05)$; those with MCM $(5 \cdot 1 \pm 0.5)$ were lower than with OM2 $(5 \cdot 6 \pm 0 \cdot 6)$ at 3 months (P <0.01); those with SCM $(5 \cdot 5 \pm 0 \cdot 5)$ lower than OM2 $(5 \cdot 9 \pm 0 \cdot 2)$ at 6 weeks $(P<0 \cdot 01)$ and 3 months $(5 \cdot 2 \pm 0 \cdot 6 / 5 \cdot 6 \pm 0 \cdot 6, \mathrm{P}<0 \cdot 05)$.

Total plasma proteins (Table 2). The mean total plasma protein value in BM-fed infants was higher than in other groups. It was higher than in the OM2 group at 6 days $(66 \cdot 0 / 60.5 \mathrm{~g} / \mathrm{l} ; \mathrm{P}<0.01)$ and 3 weeks $(70 \cdot 3 / 57 \cdot 8, P<0 \cdot 01)$, and higher than in the MCM and SCM groups at 3 months $(73 \cdot 4 / 62 \cdot 6$, $P<0.01$; and $73 \cdot 4 / 64 \cdot 5, P<0 \cdot 01)$. The mean in the MCM group was higher than in the OM2 group at 3 weeks $(66 \cdot 6 / 57 \cdot 8, P<0 \cdot 02)$, but lower at 3 months $(62 \cdot 6 / 66 \cdot 2, \mathrm{P}<0 \cdot 01)$. The SCM mean value at 6 days $(68 \cdot 3)$ was higher $(P<0.01)$ than that of the OM2 group $(60 \cdot 5)$.

Plasma amino acids (Fig. 1). Fig. 1 shows plasmafree amino acid concentrations in the three groups of infants fed cows' milk formulae as a percentage of the values found in the plasma of breast-fed infants. It can be seen that plasma amino acid concentrations in modified Carnation-fed infants were nearer breast-fed values than the unmodified milks, but throughout the first 3 months plasma concentrations were greater in all three artificially-fed groups. At
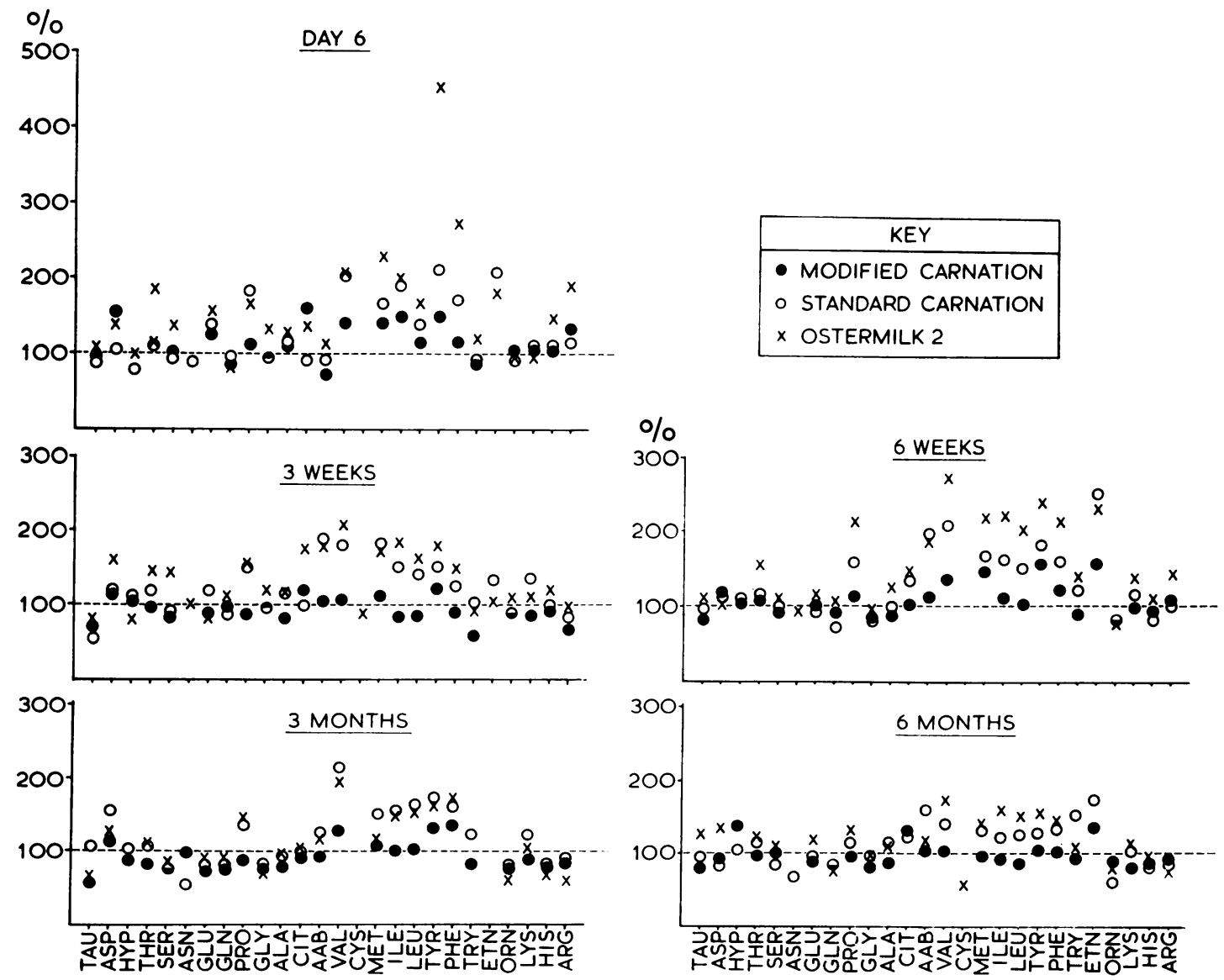

Fig. 1 Mean plasma amino acid concentrations in the first 6 months in three groups of infants fed different milks, expressed as a percentage of the mean values measured in a fourth group of breast-fed infants. 
day 6 there were already particularly high plasma concentrations of valine, methionine, tyrosine, phenylalanine, and ethanolamine in infants fed unmodified milks. Total free amino acid concentrations in infants fed SCM and OM2 were maintained between $1 \frac{1}{2}$ to 2 times that in breast-fed infants throughout the first 3 months and this was reflected in plasma urea concentrations (Table 4).

Plasma urea (Fig. 2, Table 3), urine osmolality (Table 2), and plasma osmolality (Table 4). Groups which had lower mean plasma urea also had lower urine osmolality values. Fig. 2 shows that urea values for infants fed BM $(3 \cdot 20 \pm 0 \cdot 97 \mathrm{mmol} / 1,19 \cdot 2 \pm 5 \cdot 8$ $\mathrm{mg} / 100 \mathrm{ml}$; and $3 \cdot 72 \pm 2 \cdot 29 \mathrm{mmol} / \mathrm{l}, 22 \cdot 3 \pm 13 \cdot 8$ $\mathrm{mg} / 100 \mathrm{ml})$ and $\mathrm{MCM}(3.05 \pm 0.88 \mathrm{mmol} / \mathrm{l}$, $18 \cdot 3 \pm 5 \cdot 3 \mathrm{mg} / 100 \mathrm{ml}$; and $3 \cdot 88 \pm 0 \cdot 90 \mathrm{mmol} / \mathrm{l}$, $23 \cdot 3 \pm 5 \cdot 4 \mathrm{mg} / 100 \mathrm{ml}$ ) were lower than for OM2 $(6 \cdot 22 \pm 2 \cdot 00 \mathrm{mmol} / \mathrm{l}, 37 \cdot 3 \pm 12 \cdot 0 \mathrm{mg} / 100 \mathrm{ml}$; and $6 \cdot 84 \pm 1 \cdot 26 \mathrm{mmol} / 1,41 \cdot 2 \pm 7 \cdot 6 \mathrm{mg} / 100 \mathrm{ml})$ and $\operatorname{SCM}(5 \cdot 08 \pm 1 \cdot 50 \mathrm{mmol} / 1,30 \cdot 5 \pm 9 \cdot 0 \mathrm{mg} / 100 \mathrm{ml}$; and $7 \cdot 15 \pm 1 \cdot 21 \mathrm{mmol} / 1,43 \cdot 1 \pm 7 \cdot 3 \mathrm{mg} / 100 \mathrm{ml})$ infants at both 6 days and 3 months $(P<0.01$ in all). Table 3 shows plasma urea concentrations obtained from the amino acid chromatographs and indicates

Table 3 Plasma urea concentrations ( $\mathrm{mmol} / \mathrm{l}$ )

\begin{tabular}{llrcrl}
\hline & 6 days & 3 weeks & 6 weeks & 3 months & 6 months \\
\hline BM & 1.9 & $3 \cdot 3$ & $2 \cdot 5$ & $2 \cdot 7$ & $3 \cdot 2$ \\
OM2 & $8 \cdot 6$ & 11.9 & $8 \cdot 6$ & $8 \cdot 4$ & $5 \cdot 9$ \\
MCM & $2 \cdot 2$ & $2 \cdot 2$ & 3.0 & $3 \cdot 5$ & 4.6 \\
SCM & 6.5 & $8 \cdot 7$ & $14 \cdot 2$ & 10.4 & $9 \cdot 1$ \\
\hline
\end{tabular}

Conversion: SI to traditional units-Urea: $1 \mathrm{mmol} / 1 \approx 6 \mathrm{mg} / 100 \mathrm{ml}$. that at all ages the plasma urea levels in $\mathrm{BM}$ and MCM infants were much lower than in infants on SCM and OM2.

Table 2 shows a similar position for urine osmolality values. The BM and MCM groups had significantly lower osmolalities than the OM2 and SCM groups up to 3 months ( $P<0.01$ in all, except $\mathrm{P}<0.05$ for MCM/OM2 at 6 weeks).

Despite these marked differences in plasma urea and urine osmolality there were no significant differences between the groups with respect to plasma osmolality at 6 days of age (Table 4). The

Table 4 Plasma osmolality concentrations ( $\mathrm{mOsm} / \mathrm{kg}$ ) at 6 days of age

\begin{tabular}{lcl}
\hline Group & No. & Mean $\pm S D$ \\
\hline BM & 9 & $292 \pm 9$ \\
OM2 & 12 & $290 \pm 6$ \\
MCM & 11 & $293 \pm 9$ \\
SCM & 11 & $288 \pm 6$ \\
\hline
\end{tabular}

mean values of the latter were all in the normal range although 5 of the 43 estimations were over 300 $\mathrm{mOsm} / \mathrm{kg}$.

Haematocrit and haemoglobin. No significant differences were found between any of the groups at 6 days, 3 weeks, 6 weeks, and 3 months. At 6 months of age, the mean haematocrit of MCM-fed infants $(37 \cdot 3 \% \pm 2 \cdot 2)$ was similar to that of BM-fed $(38 \cdot 1 \pm 4 \cdot 1)$ but lower than that of OM2 fed $(40 \cdot 4 \pm 2 \cdot 4)$ and SCM fed $(39 \cdot 6 \pm 2 \cdot 6)(P<0.01$ in

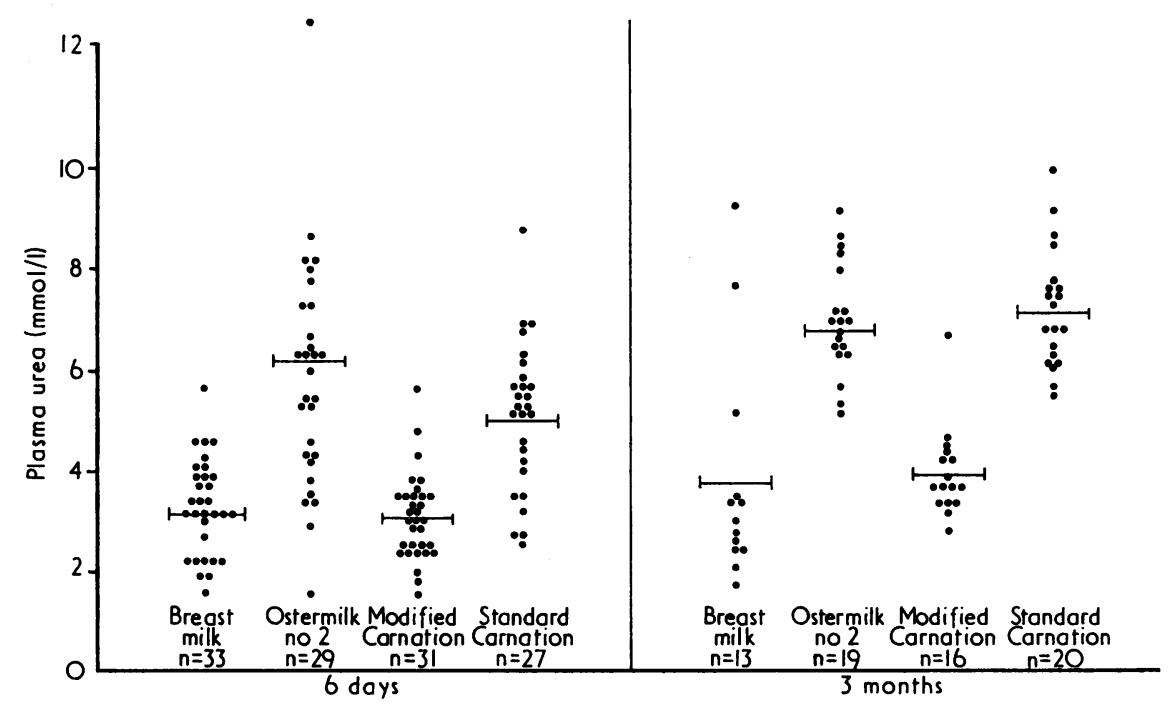

Fig. 2 Plasma urea in infants Conversion: $S I$ to traditional unitsPlasma urea: 1 mmolll $\approx 6 \mathrm{mg} / 100 \mathrm{mml}$. 
both cases). All groups showed the usual postnatal falls in haematocrit and $\mathrm{Hb}$.

Plasma glucose. No differences were evident in plasma glucose values at 6 days. Though samples were taken just before the same morning feed there was wide variation in individual values.

Lipids. (Total plasma lipids, plasma cholesterol, and plasma nonesterified fatty acids.) There were few differences between the groups. OM2 resulted in lower plasma nonesterified fatty acids at 6 days than BM $(\mathrm{P}<0.02)$ and MCM $(\mathrm{P}<0.05)$, and lower cholesterol at 6 weeks than SCM $(P<0 \cdot 01)$.

\section{Growth measurements.}

Weight. No significant differences in absolute weight were found between any of the groups, but during the first 6 months of life all artificially-fed babies showed a weight gain significantly greater than that of BM-fed infants. With MCM this increased weight gain was seen at 6 days $(P<0.01)$ and 3 weeks $(P<0.02)$, with $\mathrm{OM} 2$ and $\mathrm{SCM}$ at 6 days $(\mathrm{P}<0.01)$ and 6 months $(P<0.02)$. When weight gain data for the groups were divided by sex, males showed 10 significant differences and females 2 .

Crown-rump length. At 3 weeks female infants fed on BM and MCM were longer than those fed on OM2 (P <0.05) and the MCM-fed infants showed a greater gain in crown-rump length from birth than OM2-fed infants $(\mathrm{P}<0 \cdot 05)$.

Head circumference $(O F C)$. Of 8 significant differences relating to OFC measurements, 5 were at 6 months of age. BM and MCM infants had a greater OFC at 3 and 6 months than OM2-fed infants $(P<0.02 \mathrm{BM} / \mathrm{OM} 2 ; \mathrm{P}<0.05 \mathrm{MCM} /$ OM2), and SCM-fed infants had a greater OFC at 6 months than OM2 $(\mathrm{P}<0.05)$. BM-fed infants had a greater increase in OFC than SCM-fed at 3 weeks $(\mathrm{P}<0.02)$ and $\mathrm{OM} 2$-fed at 3 months $(P<0 \cdot 01)$. MCM-fed infants showed similar increases to BM-fed infants at 3 months and these were greater than those of OM2 infants $(P<0 \cdot 05)$.

\section{Skinfold thicknesses.}

Triceps measurements showed greater skinfold thicknesses in MCM- and SCM-fed infants compared with BM-fed infants. Subscapular measurements showed generally greater values for MCMfed infants compared with BM- and SCM-fed fed infants. Similarly, in 13 out of 16 significantly different suprailiac measurements, MCM-fed infants showed greater skinfold thickness than the infants in the other 3 groups.

\section{Discussion}

There are no absolute guidelines for assessing the quality of a new milk formula. The main aim must be to ensure that the new product is well tolerated, results in 'optimal' growth, and produces no undesirable effects such as gastrointestinal disturbance, allergy, and convulsions, and no significant disturbance of metabolism. Clinical, biochemical, and haematological assessments must be made over a reasonable period of time but the yardsticks which can be applied are limited. Complete evaluation before general usage is impossible.

The new infant formula (MCM), which is the subject of this study, derives from the concept that the composition of artificial milks for human infants should be as near as possible to that of human milk. Replication is not possible, only compromise modifications. The mineral, solute, and protein concentrations and the source of calories in cows' milk have been altered by diluting cows' milk by adding a vegetable oil mixture (corn oil and coconut oil) and carbohydrates (glucose solids). Thus, compared with a representative evaporated milk (SCM), the protein content has been reduced from 27 to $19 \mathrm{~g} / \mathrm{l}$, the fat content increased from 29 to $37 \mathrm{~g} / \mathrm{l}$, and the carbohydrate content reduced from 92 to $70 \mathrm{~g} / \mathrm{l}$. The content of $\mathrm{Na}, \mathrm{K}, \mathrm{Ca}, \mathrm{P}$, and $\mathrm{Mg}$ has been reduced and the $\mathrm{Ca}: \mathrm{P}$ ratio marginally increased from $1 \cdot 14$ to $1 \cdot 23$ (compared with a ratio of $2 \cdot 3$ for transitional human breast milk and $2 \cdot 4$ for mature breast milk found by Macy, 1949; 1.85 and 2.43 by Widdowson, $1965 ; 1.8$ and 2.3 by Davidson, 1968; 1.4 and 1.7 by Hanna et al., 1970; and 2.0 and 1.8 by Barltrop and Hillier, 1974). Barltrop and Hillier suggest that milk $\mathrm{Ca}: \mathrm{P}$ ratios are of less significance for neonatal calcium homoeostasis if the total mineral load is low, as is the case with MCM.

The most marked biochemical effects of MCM compared with a representative evaporated milk (SCM) and a dried milk powder (OM2) are in relation to plasma $\mathrm{Ca}, \mathrm{P}, \mathrm{Mg}$, amino acids, and urea concentrations, and to urinary osmolality. One of the aims of the new formulation was to reduce $\mathbf{P}$ concentration so that neonatal tetany would be less likely to occur. No cases of neonatal tetany were observed in the group of infants, admittedly small, who received MCM. Neonatal tetany has its peak incidence on the sixth day of life (Brown, et al., 1972). Its pathogenesis is not yet completely resolved. Vitamin D deficiency in the mother during pregnancy is probably a primary cause (Watney et al., 1971; Purvis et al., 1973; Watney and Rudd, 1974; Belton et al., 1975) but fetal parathyroid hypoplasia as a result of increased circulating maternal 
parathyroid hormone may be a direct cause of hypocalcaemia in the infant (Bakwin, 1937; Albright and Reifenstein, 1948; Lequin et al., 1970; Cushard et al., 1972). Phosphate loading aggravates the hypocalcaemia of hypoparathyroidism (even in the presence of concomitant calcium loading), hence reduction of phosphate intake is likely to reduce the risk of tetany. MCM feeding did not reduce the plasma $\mathbf{P}$ or raise $\mathrm{Ca}$ to the concentrations found in breast-fed infants at day 6 , but resulted in a $\mathrm{Ca}: \mathrm{P}$ ratio on day 6 nearer to that for BM and higher than that for SCM and OM2 (i.e. BM $1 \cdot 33 \pm 0 \cdot 29$, MCM $0.93 \pm 0 \cdot 16, S C M 0 \cdot 87 \pm 0 \cdot 21$, and OM2 $0 \cdot 81 \pm 0 \cdot 23)$. The $\mathrm{Ca}: \mathrm{P}$ ratio for $\mathrm{BM}$ was greater than those for the other three groups $(P<0.01)$ and that for MCM was greater than that for OM2 $(P<0.05)$. Serum immunoreactive calcitonin is high in newborn infants (Samaan et al., 1974, 1975) and may make them more sensitive to parathyroid deficiency and phosphorus loading.

Hypomagnesaemia is frequently a factor in neonatal tetany (Tsang, 1972; Cockburn, et al., 1973) and various factors such as a high phosphate load (Anast, 1964; Coussons, 1969), impaired magnesium absorption (Paunier et al., 1965; Salet et al., 1966), target unresponsiveness (Seelig, 1971), and transitory functional hypoparathyroidism (Davis et al., 1965) appear to contribute to it. Neonatal hypocalcaemia may respond to magnesium but not to calcium (Paunier et al., 1965; Davis et al., 1965; Salet et al., 1966), and Turner et al. (1975) have shown that intramuscular magnesium sulphate is a more rapid and effective treatment of an established case of neonatal hypocalcaemia than either oral calcium gluconate or oral phenobarbitone. Thus a milk which results in higher magnesium concentrations in the infant is likely to reduce the risk of neonatal tetany. MCM achieved a mean plasma $\mathrm{Mg}$ similar to that in BM-fed infants at 6 days and an even higher concentration at 3 weeks.

Hypernatraemia was not a problem in infants fed on MCM and its low protein, mineral, and solute content compared with the SCM and OM2 is reflected in the very clear differences between the groups in the serum urea and urinary osmolality results. MCM compared favourably with breast milk and is likely to confer considerable protection on infants against hypertonic dehydration and hyperelectrolytaemia. High plasma free amino acid concentrations found in infants fed unmodified milks probably reflects the higher protein intake. There is as yet no evidence of benefit or harm from persistently high plasma amino acid values. Davies and Saunders (1973) and Dale et al. (1975) found higher blood urea values in infants aged 1 to 3 months fed on artificial milk compared with breast milk. Reduction in solute load therefore appears to be an important and beneficial property of MCM. As MCM is supplied in the form of liquid evaporated milk there is likely to be less error in its reconstitution (normal dilution is $1: 1$ ) than in the reconstitution of dried milk powder where the risks of serious error have been well documented (Taitz and Byers, 1972; Wilkinson et al., 1973).

As judged on height, weight, head circumference, and skinfold thickness, MCM seems to be entirely adequate nutritionally. In common with the other two artificial milks it tends to result in infants of greater weight than those fed on breast milk, whereas the breast-fed infants and those fed MCM showed some tendency to be longer than infants given OM2. There is a greater awareness now of the risks of obesity in babies, but this is considered to be due to excessive and too early feeding with carbohydrate. It could be argued that the performance of MCM in terms of weight and length might be an argument to convince mothers that infants can develop and grow adequately on a modified cows' milk of appropriate type without additional carbohydrate until at least 4 to 6 months of age. The greater head circumference found in infants fed MCM and BM, compared with SCM and OM2, raises interesting speculations regarding brain development with different feeds.

The linoleic acid of MCM $(19.8 \%$ of the fatty acids) is considerably higher than that of other milks including that of most breast milk. However, studies have shown that the linoleic acid content of breast milk varies with the mother's diet and a mean value as high as $15 \cdot 2 \%$ was reported in a group of Jordanian mothers (Read et al., 1965). Studies by Widdowson et al. (1974) on the composition of milks on sale in seven European countries showed that 16 of the 18 milks analysed had a linoleic acid content greater than $10 \%$ and that 2 had a content of over $40 \%$. Widdowson et al. (1975) have subsequently shown that triglycerides in the adipose tissue of infants reflect the fatty acid profile of the fat in the diet. Such evidence makes it extremely difficult to decide on the nature and concentration of constituents of a milk for infant feeding.

We are grateful to the Consultant Obstetricians, Simpson Memorial Maternity Pavilion, Royal Infirmary, Edinburgh, for allowing access to mothers; to Dr. D. M. Douglas for permitting babies under his care to be studied; to Miss Mary Taylor, Nursing Officer, for her co-operation; to Mrs. S. Leadbetter, Mrs. A. Bird, and Mrs. M. H. Philp for technical analyses; and to Miss D. Housler for secretarial assistance. 


\section{References}

Albright, F., and Reifenstein, E. C. (1948). The Parathyroid Glands and Metabolic Bone Disease. Williams and Wilkins, Baltimore.

Anast, C. S. (1964). Serum magnesium levels in the newborn. Pediatrics, 33, 969-974.

Bakwin, H. (1937). Pathogenesis of tetany of the newborn. American Journal of Diseases of Children, 54, 1211-1226.

Barltrop, D., and Hillier, R. (1974). Calcium and phosphorus content of transitional and mature human milk. Acta Paediatrica Scandinavica, 63, 347-350.

Belton, N. R., Cockburn, F., Forfar, J. O., Giles, M. M., and Stephen, R. (1975). Neonatal hypocalcaemia and its relationship to vitamin $D$ and mineral metabolism in the pregnant mother. Clinical Chemistry, 21, 951.

Brown, J. K., Cockburn, F., and Forfar, J. O. (1972). Clinical and chemical correlates in convulsions of the newborn. Lancet, 1, 135-138.

Cockburn, F., Blagden, A., and Robins, S. P. (1971). Amino acid concentrations in human foetal fluids. 8th Technicon Symposium Proceedings, p. 165. Technicon Corporation, New York.

Cockburn, F., Brown, J. K., Belton, N. R., and Forfar, J. O. (1973). Neonatal convulsions associated with primary disturbance of calcium, phosphorus and magnesium metabolism. Archives of Disease in Childhood, 48, 99-108.

Coussons, H. (1969). Magnesium metabolism in infants and children. Postgraduate Medicine, 46, 135-139.

Cushard, W. G., Jr., Creditor, M. A., Canterbury, J. M., and Reiss, E. (1972). Physiologic hyperparathyroidism in pregnancy. Journal of Clinical Endocrinology and Metabolism, 34, 767-771.

Dale, G., Goldfinch, M. E., Sibert, J. R., and Webb, J. K. G. (1975). Plasma osmolality, sodium and urea in healthy breast-fed and bottle-fed infants in Newcastle upon Tyne. Archives of Disease in Childhood, 50, 731-734.

Davidson, M. (1968). Pediatrics, 14th ed., p. 148. Ed. by H. L. Barnett. Butterworths, London.

Davies, D. P. (1973). Plasma osmolality and feeding practices of healthy infants in the first three months of life. British Medical Journal, 2, 340-342.

Davies, D. P., and Saunders, R. (1973). Blood urea. Normal values in early infancy related to feeding practices. Archives of Disease in Childhood, 48, 563-565.

Davis, J. A., Harvey, D. R., and Yu, J. S. (1965). Neonatal fits associated with hypomagnesaemia. Archives of Disease in Childhood, 40, 286-290.

Department of Health and Social Security. (1974) PresentDay Practice in Infant Feeding, p. 24. HMSO, London.

Fawcett, J. K., and Scott, J. E. (1960). A rapid and precise method for the determination of urea. Journal of Clinical Pathology, 13, 156-159.

Fiske, C. H., and Subbarow, Y. (1925). The colorimetric determination of phosphorus. Journal of Biological Chemistry, 66, 375-400.

Gerstenberger, H. J., and Ruth, H. O. (1919). Studies in the adaptation of an artificial food to human milk. American Journal of Diseases of Children, 17, 1-37.

Gittleman, I. F., and Pincus, J. B. (1951). Influence of diet on the occurrence of hyperphosphatemia and hypocalcemia in the newborn infant. Pediatrics, 8, 778-787.

Gornall, A. G., Bardawill, C. J., and David, M. M. (1949). Determination of serum proteins by means of the biuret reaction. Journal of Biological Chemistry, 177, 751-766.

Hanna, F. M., Navarette, D. A., and Hsu, F. A. (1970). Calcium-fatty acid absorption in term infants fed human milk and prepared formulas simulating human milk. Pediatrics, 45, 216-224.
Jamieson, A. (1964). A method for the rapid determination of serum total cholesterol using a modification of the Pearson reaction. Clinica Chimica Acta, 10, 530-535.

Kingsley, G. R. (1939). The determination of serum total protein, albumin and globulin by the biuret reaction. Journal of Biological Chemistry, 131, 197-200.

Lequin, R. M., Hackeng, W. H. L., and Schopman, W. (1970). A radioimmunoassay for parathyroid hormone in man. Acta Endocrinologica, 63, 655-666.

Macy, I. G. (1949). Composition of human colostrum and milk. American Journal of Diseases of Children, 78, 589-603.

Novak, M. (1965). Colorimetric ultramicro method for the determination of free fatty acids. Journal of Lipid Research, 6, 431-433.

Oates, R. K. (1973). Infant feeding practices. British Medica Journal, 2, 762-764.

Oppé, T. E., and Redstone, D. (1968). Calcium and phosphorus levels in healthy newborn infants given various types of milk. Lancet, 1, 1045-1048.

Paunier, L., Radde, I. C., Kooh, S. W., and Fraser, D. (1965). Primary hypomagnesemia with secondary hypocalcemia. (Abst.) Journal of Pediatrics, 67, 945.

Purvis, R. J., Barrie, W. J. M. K., Mackay, G. S., Wilkinson, E. M., Cockburn, F., Belton, N. R., and Forfar, J. O. (1973). Enamel hypoplasia of the teeth associated with neonatal tetany: a manifestation of maternal vitamin-D deficiency. Lancet, 2, 811-814.

Raabo, E., and Terkildsen, T. C. (1960). On the enzymatic determination of blood glucose. Scandinavian Journal of Clinical and Laboratory Investigation, 12, 402-407.

Read, W. W. C., Lutz, P. G., and Tashjian, A. (1965). Human milk lipids. 2. The influence of dietary carbohydrates and fat on the fatty acids of mature milk. A study in four ethnic groups. American Journal of Clinical Nutrition, 17, 180-183.

Salet, J., Polonovski, C., de Gouyon, F., Pean, G., Melekian, B., and Fournet, J. (1966). Tetanie hypocalcemique recidivante par hypomagnesemie congenitale. Archives Françaises de Pédiatrie. 23. 749-758.

Samaan, N. A., Wigoda, C., and Castillo, S. G. (1974). Human serum calcitonin and parathyroid hormone levels in the maternal, umbilical cord blood and postpartum. Calcitonin: Proceedings of the Fourth International Symposium, p. 364. Ed. by S. Taylor and G. V. Foster. Heinemann, London.

Samaan, N. A., Anderson, G. D. and Adam-Mayne, M. E. (1975). Immunoreactive calcitonin in the mother, neonate, child and adult. American Journal of Obstetrics and Gynecology, 121, 622-625.

Seelig, M. (1971). Human requirements of magnesium. Factors that increase need. Proceedings of the Ist International Symposium on Magnesium Deficit in Human Pathology, p. 11. Ed. by J. Durlach. Vittel, France.

Shaw, J. C. L., Jones, A., and Gunther, M. (1973). Mineral contents of brands of milk for infant feeding. British Medical Journal, 2, 12-15.

Taitz, L. S., and Byers, H. D. (1972). High calorie/osmolar feeding and hypertonic dehydration. Archives of Disease in Childhood, 47, 257-260.

Tanner, J. M. (1973). Physical growth and development. Textbook of Paediatrics, p. 230. Ed. by J. O. Forfar and G. C. Arneil. Churchill Livingstone, Edinburgh.

Tsang, R. C. (1972). Neonatal magnesium disturbances. American Journal of Diseases of Children, 124, 282-293.

Turner, T. L., Cockburn, F., Giles, M. M., Cohen, M., and Forfar, J. O. (1975). Treatment of neonatal tetany. Pediatric Research, 9, 857.

Watney, P. J., and Rudd, B. T. (1974). Calcium metabolism in pregnancy and the newborn. Journal of Obstetrics and Gynaecology of the British Commonwealth, 81, 210-219. 
Watney, P. J., Chance, G. W., Scott, P., and Thompson, J. M. (1971). Maternal factors in neonatal hypocalcaemia: a study in three ethnic groups. British Medical Journal, 2, 432-436.

Widdowson, E. M. (1965). Absorption and excretion of fat, nitrogen, and minerals from 'filled' milks by babies one week old. Lancet, 2, 1099-1104.

Widdowson, E. M., Southgate, D. A. T., and Schutz, Y. (1974). Comparison of dried milk preparations for babies on sale in 7 European countries. I. Protein, fat, carbohydrate and inorganic constituents. Archives of Disease in Childhood, 49, 867-873.

Widdowson, E. M., Dauncey, M. J., Gairdner, D. M. T., Jonxis, J. H. P., and Pelikan-Filipkova, M. (1975). Body fat of British and Dutch infants. British Medical Journal, 1, 653-655.
Wilkinson, P. W., Noble, T. C., Gray, G., and Spence, O. (1973). Inaccuracies in measurement of dried milk powders. British Medical Journal, 2, 15-17.

Zöllner, N., and Kirsch, K. (1962). Úber die quantitative Bestimmung von Lipoiden (Mikromethode) mittels der vielen natürlichen Lipoden (allen bekannten Plasmalipoiden) gemeinsamen Sulfophosphovanillin-reaktion. Zeitschrift für die Gesamte Experimentelle Medizin, 135, 545-561.

Correspondence to Dr. N. R. Belton, Department of Child Life and Health, 17 Hatton Place, Edinburgh EH9 1UW. 